\title{
Books Forum: Introduction
}

Javier Lezaun (Reviews Editor)

Institute of Science, Innovation and Society, Said Business School, University of Oxford, Park End Street, Oxford OX1 1HP, UK

E-mail: Javier.Lezaun@sbs.ox.ac.uk

Four books make up this rather eclectic forum. Alberto Cambrosio reviews Hannah Landecker's Culturing life, María Puig de la Bellacasa reviews Melinda Cooper's Life as surplus, Andrew Pilsch reviews Priscilla Wald's Contagious, and Carlos Andrés Barragán reviews the collection Tactical biopolitics, edited by Beatriz da Costa and Kavita Philip.

There is, perhaps, an underlying thread connecting these four works: an emphasis on the bewildering potentialities of life in its multiple biological forms-virus, cell, tissue, animaland a desire to scrutinize how those potentialities are incorporated-enhanced, channelled, exploited, constrained-in scientific, economic, cultural and artistic regimes of value. That interesting things tend to happen when novel means of making life malleable encounter conventional human practices-whether it is generating economic profit, creating scientific knowledge, or producing works of art.

In any event, these are, yet again, examples of the burgeoning, almost bubbling state of the social studies of life and the life sciences. Three years ago, in our first 'Books Forum', Nathan Greenslit announced the journal's intention to offer a space for 'crossdisciplinary conversations' and a desire to 'guard against the specialization of vocabulary' that often obtains in academic discourse. Our experimentation with different formats for this section has been a way of offering vehicles for engaging with the explosion of literatures in the fields covered by this journal.

Whether the result has been cross-disciplinary or merely eclectic is probably not that important. What is more relevant, and what the four books and the four reviews in this issue suggest, is a certain confluence of themes and questions across very diverse subject areas and intellectual agendas; and the value that the social sciences and humanities can extract from encounters with biotechnological life. 